\title{
KARL RAIMUND POPPER Problem Neopositivistik dan Teori Kritis Falsifikasi
}

\author{
M. Syamsul Huda
}

\begin{abstract}
A bstract: Karl Popper once criticizes the positivistic paradigm by means of what he calls the theory of falsification. To him, the positivistic paradigm constitutes a failure simply because it cannot distinguish between science and prude science, that is, between empirical method and non-empirical method. In the scientific knowledge, empirical science, mathematics and logic must be differentiated, something that the positivistic paradigm has failed to do. This paradigm furthermore, did not have a clear picture what logicbased science is, empirical knowledge and psychology of knowledge. It also fails to properly understand knowledge that springs from tradition, emotion, authority and so forth. All positivistic paradigms such as that of Karl Max's Historicism, Freud's theory of Psycho Analysis, Adler's theory of Individual Analysis and Newton's theory of Gravitation fall into this trap of failure.
\end{abstract}

Keywords: induction, deduction, falsification, prude science, empirical and non-empirical science

\section{Pendahuluan}

Karl Popper adalah salah satu kritikus yang paling tajam terhadap gagasan lingkaran Wina. ${ }^{1}$ Karena lingkaran ini dianggap menjadi mesin yang memproduk dan pengembang aliran neopositivistik, yang pro terhadap metode berfikir induktivistik. Menurutnya metode ini mengalami kegagalan, karena tidak dapat membedakan antara science (pengetahuan ilmiah) dan preude science (pengetahuan semu) atau empirical method and a non empirical method ${ }^{2}$ dalam standar kriteria ilmu maupun sistem antara empirical science dengan matematics and logic as metaphysical'3sehingga ilmu pengetahuan sulit untuk dibedakan, mana yang berdasarkan logika dan fakta empirik (empirical fact) dan mana pengetahuan berdasarkan pengalaman pribadi (psychology of knowledge) yang dipengaruhi oleh tradisi, emosi, otoritas dan lain sebaginya.

Sebagaimana Karl Marx, dengan teori Sejarahnya, ${ }^{4}$ Freud dengan teori Psychoanalysisnya,

\footnotetext{
* Fakultas U shuluddin IAIN Sunan Ampel Surabaya.

${ }^{1}$ Kelompok Lingkaran Wina (Austria) concern terhadap ilmu pengetahuan, filsafat, matematika dan politik dengan pendekatan teori Verifikatif. Nama-nama Alfred Ayer, Viktor Kraft , Herbeert Feigl Morre ,Rusell William Berkson, Psikologi Belajar Karl Popper, Terj, Ali Noer Zaman (Yogjakarta: Qalam, 2003), 5.

${ }^{2}$ Ibid., 151

${ }^{3}$ Karl R. Popper, The Logic of Scientific Discovery (London : Routledge, 1992). 34.

${ }^{4}$ Tak seorangpun paham bahwa sejarah Marxisme dapat membuat kesalahan. Marxisme adalah teori historis murni, yang tujuan memprediksi jalannya perkembangan-perkembangan ekonomi dan politik kekuasaan masa depan dan khususnya tentang jalan revolusi. Dengan demikian, Marxisme tidak memberikan kebijakan bagi partai Komunis Rusia setelah kemunculan kekuasaan politik, karena Marx secara praktis telah melarang semua (bentuk) teknologi sosial, yang ia cela sebagai U topia. Harus dicatat bahwa bukan karena doktrin determinisme yang abstrak dan teori yang menyesatkanMarx, namun lebih disebabkan karena pengaruh praktis doktrin ini pada pandangan metode saintifiknya, pada pandangannya tentang tujuan-tujuan dan kemungkinan-kemungkinan ilmu pengetahuan sosial. Lihat Karl R. Popper, M asyarakat Terbuka dan Musuh-musuhnya, terj, Uzair Fauzan, (Yogjakarta: Pustaka Pelajar, 2002), 345.
} 
Adler dengan teori Individual Analisis ${ }^{5}$ serta Newton dengan teori gravitasi juga memcampuradukkan antara pengetahuan ilmiah dengan pengetahuan semu. Di samping itu, pada masa Popper hidup, ilmu pengetahuan telah dikuasai oleh Induktivistik, yaitu aliran yang menjadikan pengamatan dan pengalaman menjadi bukti keobyektifan sebuah teori tanpa ada yang mengkritisinya seolah-olah kebenaran ilmu menjadi mutlak.

Kondisi yang demikian menjadi kegelisahan bagi Popper untuk mengkontruksi cara berfikir induktif menjadi deduktif. la melihat beberapa titik kelemahan metode Induktif. Pertama, Induktifis menarik hukum-hukum (statemen singular) menjadi bersifat umum (general) pada ilmu pengetahuan yang bersumber dari pengalaman dan observasi serta fakta-fakta empirik. Kedua, Teori atau pernyataan - pernyataan (statemen ) ilmu pengetahuan dari hasil observasi dan pengalaman tidak bersifat ilmiah karena belum diuji (testable) dan diuji kepalsuan (falsifiability) ${ }^{6}$ sehingga banyak yang menyesatkan, baik dalam perspektif sejarah (historis), kejiwaan (psychology), Teori fisika (Newton) maupun ilmu sosial.

Di sinilah problem fundamental yang dihadapi oleh Karl Popper pada zamannya. Sebagai antitesa atas kesalahan para penganut induktifis, maka Popper menawarkan sebuah gagasan dengan cara uji kesalahan (falsifiable) dan uji logika realita (testability) Dengan harapan sebuah teori benar-benar dari hasil uji kesahihan yang empirik serta bebas dari prasangka, ramalan, prediksi yang bersifat personal.

Berdasarkan paparan problema yang dihadapi oleh Popper, penulis akan mendeskripsikan problem Induktif, damarkasi antara Science dan Preudo science, serta gagasan pemurnian ilmu pengetahuan dengan teori Falsifikasi.

\section{Lintasan Riwayat Hidup Karl Popper.}

Karl Raimund Popper lahir di Wina pada tanggal 28 J uli tahun 1902. Ayahnya Dr. Simon Sigmund Carl Popper seorang pengacara yang sangat minat pada Filsafat. Perpustakaannya luas mencakup kumpulan-kumpulan karya filsuf besar dan karya-karya mengenai problem sosial. Agaknya Karl Popper mewarisi minatnya pada filsafat dan problem sosial dari ayahnya. ${ }^{7}$ O rang tuanya keturunan Yahudi, tetapi tidak lama setelah menikah mereka berdua dibabtis dalam gereja Protestan. Ayahnya adalah sarjana hukum dan pengacara yang mencintai buku, dan musik.

Pada umur 16 tahun Popper meninggalkan sekolahnya "realgymnasium" dengan alasan bahwa pelajaran-pelajarannya sangat membosankan. Lalu ia menjadi pendengar bebas pada Universitas Wina dan baru tahun 1922 ia diterima sebagai mahasiswa.

\footnotetext{
${ }^{5}$ Suatu dalil bahwa tindakan manusia didorong oleh perasan semacam inferioritas. Misalnya kasus seorang laki-laki tidak mau menolong seorang anak yang terseret oleh arus, karena takut dan karena ia memutuskan tidak menolong. Keputusan tidak menolong ini dibenarkan oleh Adler, karena laki-laki tersebut telah mengatasi perasaan inferioritas mendemontrasikan bahwa ia mempunyai kemauan keras untuk tetap berdiri di tepi sungai.Chalmer, A pa Itu Yang Dinamakan Pengetahuan (J akarta: Hasta Mitra, 1963), 43.

${ }^{6}$ William Berkson, Psikologi Belajar dan Filsafat Ilmu Karl Popper, ter. Ali Noer Zaman (Yogjakarta: Qalam, 2003), 31.

${ }^{7}$ Alfon Taryadi, Epistemologi Pemecahan Masalah M enurut Karl R Popper (J akarta: Gramedia, 1991),1.
} 
Ketika umur 17 tahun, selama beberapa tahun ia menganut komunisme, tetapi tidak lama kemudian ia meninggalkan aliran politik ini, karena ia yakin bahwa penganutnya menerima begitu saja suatu dokmatisme yang tidak kritis dan ia menjadi anti Marxis untuk seumur hidup. ${ }^{8}$ Perjumpaannya dengan Marxisme diakui olehnya sebagai satu di antara peristiwa penting dalam perkembangan intelektualnya. Dalam outobiografinya bercerita bahwa ia mengikuti aneka macam kuliah, tentang sejarah, kesusasteraan, psikologi, filsafat bahkan tentang ilmu kedokteran.

Pada tahun yang sama tahun 1919, Popper mendengar apa yang dikerjakan oleh Einstein dan menurut pengakuannya merupakan suatu pengaruh dominan atas pemikirannya, bahkan dalam jangka panjang pengaruhnya sangat berarti. ${ }^{9}$ Dalam suatu waktu Popper mendengarkan ceramah Einstein di Wina. Ia terpukau oleh sikap Einsten terhadap teorinya yang tidak dapat dipertahankan kalau gagal dalam tes tertentu. Ia mencari eksperimen-eksperimen yang kesesuaiannya dengan ramalan-ramalannya belum berarti meneguhkan teorinya.

Sedangkan ketidaksesuaian antara teori dengan eksperimen akan menentukan apakah teorinya bisa dipertahankan atau tidak. Sikap ini menurutnya berlainan dengan sikap Marxis yang dogmatis dan selalu mencari pembenaran-pembenaran (verifikasi) terhadap teori kesayangannya. Sampai pada kesimpulan bahwa sikap ilmiah adalah sikap kritis, yang tidak mencari pembenaran-pembenaran melainkan tes yang serius, pengujian yang dapat menyangkal teori yang diujinya, meskipun tak pernah dapat meneguhkannya.

Pada tahun 1928 ia meraih gelar Doktor Filsafat dengan suatu disertasi tentang Zur Methodenfrage der Denkp Psychologei (Masalah Metode dalam Psikologi Pemikiran), suatu karangan yang tidak diterbitkan. Pada tahun berikutnya Popper memperoleh gelar Diploma pada bidang Matematika dan ilmu pengetahuan Alam.

Dalam catatan sejarah, Popper tidak pernah menjadi anggota Lingkaran Wina, tetapi ia mengenal anggota Lingkaran Wina yang bekerja di universitas dan pada beberapa di antara mereka, ia mempunyai hubungan khusus dengan anggota Lingkaran Wina di antaranya Viktor Kraft, Herert Feigl. Dalam usaha studinya, Popper belajar banyak dari Karl Buhler, Profesor Psychologi di Universitas Wina yang paling penting dalam perkembangannya di masa mendatang ialah teori Buhler tentang tiga tingkatan bahasa yaitu fungsi ekspresi, fungsi stimulasi dan fungsi deskriptif. Menurut Buhler fungsi pertama selalu hadir pada bahasa manusia maupun binatang, sementara fungsi yang ketiga khas pada bahasa manusia. Popper sendiri kelak menambahkan fungsi yang keempat yaitu fungsi argumentatif, yang dianggap penting karena merupakan basis pemikiran krisis.

Pada tahun kedua di Institut Pedagogis, Popper berjumpa dengan Prof H einrich G omperz dan banyak dimanfaatkan untuk berdiskusi dengan problem psikologi pengetahuan atau psikologi penemuan. ${ }^{10} \mathrm{H}$ asil pertemuannya dengan Prof. Heinrich melahirkan keyakinan Popper bahwa data indrawi, data atau kesan sederhana itu semua khayalan yang berdasarkan usaha keliru yang mengalihkan Atomisme dari fisika ke psikologi.

${ }^{8} \mathrm{~K}$ B ertens, Filsafat B arat Kontemporer Inggris-J erman (J akarta : G ramedia, 2003), 72.

${ }^{9}$ Alfon, Epistemologi, 3.

${ }^{10}$ Alfons, Epistemologi, 4. 
Sesudah perang dunia II selesai, Popper diangkat sebagai dosen di London School of Economics, sebuah institut di bawah naungan Universitas London. Di sini ia mempersiapkan suatu buku yang menguraikan perkembangan pemikirannya sejak buku The Logic of Scientific Discovery, di antara buku yang diterbitkan antara lain Realism and Aim of Science: Quantum Theory and the Schism in Physics The Open Sociaty and Its Enemies, dan The Poverty of $\mathrm{H}$ istoricism yang memberi analisis dan kritik Popper atas pemikiran tiga tokoh yang menurut dia termasuk historisisme, yaitu Plato, Hegel, dan Marx.

Pada tahun 1977 Popper banyak memberikan ceramah dan kuliah tamu di Eropa, Amerika, J epang dan Australia. Ia banyak mengenali secara pribadi ahli-ahli kimia modern yang besar seperti, Albert Einstein, Neil Bohr, Edwin Schrodinger. Popper meninggal dunia pada tanggal 17 September 1994 di Croydon, London Selatan, dalam usia 92 tahun akibat komplikasi penyakit kanker. Menjelang akhir hayatnya beberapa karyanya diterbitkan dengan bantuan orang lain. Buku yang paling penting dari periode terakhir ini adalah A World of Propensities (1999) dimana ia menguraikan pemikiran definitifnya tentang probabilitas dalam logika dan Ilmu Pengetahuan. ${ }^{11}$

\section{Problem Demarkasi Sciense.}

Salah satu hal yang banyak merepotkan para anggota Lingkaran Wina ialah percobaan untuk merumuskan apa yang disebutnya prinsip Verifikasi (the Principle of Verification), artinya Teori yang tidak dapat ditangguhkan suatu yang positif sehingga prinsip yang memungkinkan untuk membedakan antara pengetahuan empirik dan metafisika atau memberikan batas ilmu (Science) dengan preudo ilmu (preudo science). ${ }^{12}$ Menurut Popper kelompok Wina masih bertautan erat dengan konsep tentang ilmu pengetahuan yang menjunjung tinggi induksi. la tergugah untuk mempertanyakan status ilmiah teori-teori Marx, Freud, Adler dengan mencari pembenaran teori-teori (verifikasi) mereka.

Science yang sejati menurut Popper adalah sikap kritis yang tidak mencari verifikasi atas teorinya, melainkan tes-tes yang akan mereputasikannya, meski tak akan pernah mengukuhkannya. Dengan kata lain kriterium demarkasi antara ilmu dan pseudo ilmu ialah falsifiabilitas (pernyataan bisa disangka). Contoh kriteria ilmu pengetahuan (science yang benar sebagaimana usaha Einstein tentang teori gravitasi. Teori gravitasi Einsten menyimpulkan bahwa cahaya meski mengalami daya tarik oleh benda-benda besar seperti matahari. Maka bisa dihitung bahwa cahaya bintang tertentu tampak berposisi dekat dengan matahari akan mencapai bumi dari arah sedemikian rupa sehingga tampaknya bintang itu sedikit bergeser dari bumi. Dalam menyusun teori Einsten tidak menggunakan ramalan-ramalan atau mencari dalil-dali untuk memperkuat keyakinannya, akan tetapi ia mencari eksperimen-eksperimen crusial (serius). $\mathrm{H}$ al ini berbeda dengan kelompok Induktifis yang diwakili oleh Marx, Freud dan Adler yang dalam pengamatan Popper melakukan kesalahan dengan memasukkan sesuatu yang tidak sebenarnya Preudo Science menjadi Science. Di antara problem itu antara lain: pertama, Kelompok Induktifis

${ }^{11} \mathrm{~K}$ B erten, Filsafat Barat, 76.

${ }^{12}$ Karl Popper, Conjectures and refutation ( N ew York: Basic Book, 1962), 151. 
membangun sistem ide yang membuat alasan-alasan palsu seolah-olah seperti ilmiah sebagaimana yang dilakukan oleh Marx ${ }^{13}$.

Semestinya science harus dihasilkan dari hukum-hukum yang sebenarnya, bisa dibuktikan melalui observasi dan eksperimen yang teruji, artinya ilmu pengetahuan harus bebas nilai. Kedua, Menafsirkan setiap fenomena dari sistem yang mereka percayai, kesalahan itu dapat dibuktikan dengan teori Hukum $\mathrm{G}$ ravitasi Newton ${ }^{14}$. Hal ini bertolak belakang dengan prinsip yang dibangun oleh Einstein yang mengambil jalan dengan melakukan eksperimen-eksperimen yang selalu diuji, sehingga terbebas dari kesalahan interpretasi sebuah fenomena yang berubahubah. Ketiga, Membuat kriteria demarkasi pengetahuan dengan berpegang pada prinsip Verifiabel menolak pengetahuan yang tidak bersumber dari fakta, termasuk menolak metafisika karena dianggap tidak bermakna. Bagi Popper prinsip verifikasi tidak akan pernah mungkin untuk menyatakan kebenaran-kebenaran hukum umum, karena hukum umum dalam ilmu pengetahuan tidak pernah dapat diverifikasi. Seluruh ilmu pengetahuan alam yang sebagian besar dari hukum-hukum umum tidak bermakna. Popper mengatakan bahwa dalam sejarah dapat kita saksikan acapkali ilmu pengetahuan lahir dari pandangan-pandangan metafisika atau mistik tentang dunia, sebagai contoh gagasan atomisme Demokritos dan Leukippos. Suatu ucapan metafisika bukan saja dapat bermakna, tetapi dapat benar juga, biarpun baru menjadi ilmiah kalau sudah teruji dan dites. ${ }^{15}$ Untuk menyelidiki suatu ucapan atau teori, lebih dahulu kita harus mengerti akan teori itu. Tetapi bagaimana kita dapat mengerti suatu teori, jika teori itu tidak mengandung makna, karena lisan itulah Popper menolak usaha neopositivisme untuk menetapkan suatu prinsip verifikasi. Keempat, Kelompok induktifistik meletakkan posisi konsep ilmu dalam kondisi statis, hal itu dapat dilihat dari komponen struktur ilmu.

Komponen-komponen itu mereka temukan dari pernyataan-pernyataan protokol yang menggambarkan komponen terakhir struktur dunia empiris. Bagi mereka induksi merupakan bagian esensi metode ilmiah dari fakta-fakta dasar, observasi, pengalaman indera. J adi intinya, dalam konsep mencari pembenaran obyektif ilmu dengan cara memperteguh pengetahuan yang tidak diragukan dan kemudian mereduksi secara logis pengetahuan lain sehingga tak tergoyahkan. ${ }^{16}$ Ini semua berlawanan dengan Popper yang memandang ilmu pengetahuan secara dinamis. Baginya mencari obyektifitas ilmu berarti membentuk kriteria rasional untuk memperoleh pengetahuan dan untuk memahami pertumbuhan pengetahuan. Menurutnya kriterium pembeda antara ilmu dan non ilmu ialah falsifiabilitas: suatu pernyataan bersifat ilmiah bila bisa difalsifikasikan secara empirik, sehingga tak ada ruang untuk pengetahuan yang absolut dan untuk kelas istimewa pernyataan-pernyataan sebagai inti kokoh pengetahuan yang tak

\footnotetext{
${ }^{13}$ Lihat: Permulaan tahun 1920, Karl Marx dan para pengikutnya telah mengklaim status keilmiahan dari teori Marx dan aliran Marxisi menggunakan klaim untuk mendukung seruan mereka pada kekerasan guna mempersiapkan dan mengurangi rasa sakit saat melahirkan tatanan sosial baru yang menurut mereka tak terelakkan. William, Psikologi Belajar, 29.

${ }^{14} \mathrm{~N}$ ewton menyamakan kekuatan total sebuah obyek dengan tingkat perubahan dalam momentumnya. J ika ada sebuah kekuatan positif dalam sebuah obyek namun tidak terjadi perubahan momentum, maka hukum Newton tertolak, William, Psikologi belajar, 31.

${ }^{15} \mathrm{~K}$. B erten, Filsafat Barat, 81.

${ }^{16} \mathrm{~A}$ Ifon, Epistemologi, 44-45.
} 
tergoyahkan. Meskipun tidak tak bisa diverifikasi secara positif, teori bisa diuji. Obyektifitas pernyataan ilmiah, bagi Popper terletak dalam kenyataan bahwa pernyataan tersebut dapat diuji secara intersubyektif.

\section{Problem Induksi}

Menurut Popper, metode induktif meninggalkan banyak masalah dalam ilmu pengetahuan, masalah itu apakah menyangkut proses cara memperoleh pengetahuan, ukuran validitas kebenaran, hasil pengetahuannya bersifat subyektif dan lain sebagainya. ${ }^{17}$ Pertama, dalam proses penyelidikan misalnya, kaum induktivis menggunakan observasi dan pengalaman sebagai dasar satu-satunya dalam membuat pernyataan tunggal (singular statemen) dan kemudian hasil pengamatan dan pengalaman pribadi yang belum teruji dapat ditarik sebuah kesimpulan berupa teori, ironinya kebenarannya bersiftat general (berlaku secara umum). Teori-teori ilmiah ditarik dengan cara ketat dari fakta-fakta pengalaman yang diperoleh lewat observasi dan eksperimen. IImu didasarkan atas apa yang dapat dilihat, didengar, diraba, dan sebagainya. ${ }^{18}$ Pengetahuan akan diterima bila berasal dari sense, expretion, (sensasional impresion, perseptian visual or auditory ${ }^{19}$.

Prinsip di atas dipertanyakan oleh Popper terutama volume eksperimen, berapa banyak observasi yang diperlukan untuk memenuhi? Haruslah sebatang logam tertentu dipanasi 10 kali, 100 kali atau seberapa banyak kali sebelum kita dapat menyimpulkan logam selalu memuai bila dipanaskan. Di sini sebenarnya tingkat kesulitan yang dihadapi oleh kelompok Induktifis, bila mereka mensyaratkan observasi dan eksperimen jadi acuan ilmu pengetahuan. ${ }^{20}$

Sanggahnya, penarikan kesimpulan ini sangat berbahaya, sebagaimana Karl Maxs telah membuat teori sejarah dengan ramalan-ramalan/prediksi yang salah tentang masyarakat kelas. J uga contoh lain mereka punya anggapan bahwa semua angsa berwarna putih tanpa memperdulikan angsa yang berwarna lain, Kertas Litmus berubah menjadi merah bila dicelupkan ke dalam cairan tanpa merinci cairan apa yang dapat merubah. Kedua,tugas bagi ilmu pengetahuan adalah merumuskan hukum-hukum yang bersifat umum dan mutlak. J ika mencari contoh yang sederhana: pernyataan bahwa logam yang dipanaskan akan memuai "merupakan hukum " bagimana hukum ilmiah serupa itu sampai terbentuk, pasti jawabanya bahwa hukum itu dihasilkan oleh suatu proses induktif. Artinya dari sejumlah kasus yang cukup besar (bermacam-macam logam yang memuai setelah dipanaskan), disimpulkan bahwa dalam keadaan yang tertentu gejala yang sama dan dimana-mana akan terjadi. Pendek kata metode ini dijalankan dengan observasi dan eksperimen serta berdasarkan fakta-fakta. Teori ini mendapatkan catatan dari David H ome. la menyatakan bahwa dari sejumlah fakta berapapun besar jumlahnya, secara logis tidak dapat disimpulkan suatu kebenaran umum. Tidak ada keharusan logis bahwa fakta-

\footnotetext{
${ }^{17}$ Karl Popper, The Logic , 28.

${ }^{18}$ Chalmer, Apa itu pengetahuan , 2

${ }^{19}$ Karl Popper, The Logic, 35.

${ }^{20}$ Contoh kelemahan dapat dilihat dari ilustrasi , seorang induktifis yang keras kepala mungkin harus menempatkan tangannya beberapa kali di atas api sebelum menyimpulkan bahwa api itu panas dan membakar. Dalam keadaan seperti ini tuntutan observasi tidak masuk akal. Chelmer, A pa itu, pengetahuan16.
} 
fakta yang sampai sekarang selalu berlangsung dengan cara yang sama. ${ }^{21}$ Dengan demikian bahwa induksi tidak dapat dibenarkan berdasarkan logika. Ketiga, Induktifis mengunakan ilmu bantu lain yaitu Logika dan Probabilitas (kemungkinan) selain dasar observasi dan eksperiman untuk mendapatkan justifikasi. Bantuan logika ini dilakukan untuk memperkokoh argumen logis dari cara penarikan kesimpulan dari pernyataan-pernyataan yang mereka buat. Misalnya argumen yang logis yang valid ditandai dengan fakta bahwa apabila premis argumen itu benar, maka kesimpulannya benar, tetapi ternyata tidak demikian.

Argumen-argumen induktif tidak merupakan argumen-argumen yang valid secara logis, masalahnya bukanlah apabila premis suatu penyimpulan induktif benar, maka kesimpulannya mesti benar. Bisa saja penyimpulan terjadi penyimpulan argumen induksi salah, sedangkan premisnya benar dan ini terjadi tanpa harus merupakan kontradiksi. Misalnya tentang pernyataan semua gagak adalah hitam..$^{22}$ karena sampai hari ini saya telah melakukan observasi terhadap sejumlah besar burung gagak pada variasi yang luas dan telah menyaksikan mereka semua hitam dan berdasarkan fakta. Ini adalah satu penyimpulan induktif yang valid dan sempurna. Menurut Popper secara premis itu benar, akan tetapi secara logis itu salah, sebab tidak ada jaminan logis bahwa gagak yang saya observasi kemudian tidak ada yang berwana coklat atau merah jambu. Kalau hal ini terbukti mana kesimpulan; semua gagak hitam itu salah. J adi penyimpulan induktif awal yang jelas valid karena memenuhi kriteria yang telah dispesifikasi oleh prinsip induksi, dapat membawa ke satu kesimpulan yang salah, sekalipun fakta menunjukkan bahwa semua premisnya benar.

Prinsip Probabilitas dipinjam oleh induktif untuk mencari alternatif jawaban jika kebenaran atas bukti tunggal dipersalahkan. Mereka menyatakan bahwa pengetahuan bukanlah pengetahuan yang telah dibuktikan, melainkan pengetahuan yang probabel benar, semakin besar jumlah observasi yang membentuk dasar suatu induksi dan semakin variasi kondisi dimana observasi dilakukan, maka semakin besar pula probalilitas hasil generalisasi itu benar. Mungkin dapat diterima secara intuitif bahwa waktu dukungan observasi terhadap hukum universal meningkat, maka probabilitas kebenaran hukum itupun meningkat, namun intuisi ini tidak akan dapat diuji. ${ }^{23}$

\section{Falsifikasi sebagai Epistemologi Pemecahan Masalah.}

Berbeda dengan cara induktif, falsifikasi menggunakan cara kerja ilmu pengetahuan tidak hanya menggunakan observasi dan pengalaman sebagai dasar di dalam menentukan hukumhukum ilmu pengetahuan (generalisasi), akan tetapi masih ada prasyarat lain yaitu uji kesalahan (Falsifiable) melalui uji kesahihan (testable). Menurutnya Falsifikasi adalah untuk mematahkan sesuatu keadaan yang salah, tidak benar ${ }^{24}$. Suatu teori dapat dikatakan salah, jika meminta bantuan pada hasil observasi dan eksperimen tanpa percobaan dan kesalahan (Trial and Error)

\footnotetext{
${ }^{21}$ Lihat Tidak ada kepastian logis bahwa besok pagi matahari terbit. Kita berpikir demikian karena suatu kecenderungan psikologis, bukan karena suatu keharusan logis. K Berker, Filsafat Barat, 78.

${ }^{22}$ Ibid.

${ }^{23}$ Ibid., 29.

${ }^{24}$ Chalmers, Apa itu Pengetahuan, 39.
} 
melalui dugaan dan penolakan hanya teori yang paling cocok dapat dipertahankan untuk menghindarkan kesalahan-kesalahan yang pernah dilakukan oleh Neopositivisme, Popper membuat sistem kerja ilmu dengan teori Falsifikasi. Pertama, Suatu pengetahuan empirik/ilmiah dinyatakan benar, bila sistem tersebut dapat diuji (Falsifiabilitas) dan bukan veriabilitas. Contohnya Esok akan hujan, karena secara empiris dapat disangkal. Popper mengusulkan tentang Falsifiabilitas sebagai kriteria demarkasi didasarkan pada suatu asimetri antara verifialitas dan falsifiabilitas, sebab pernyataan universal tidak dapat berasal dari pernyataan tunggal, sebaliknya dapat dikontradiksikan oleh penyataan singular. ${ }^{25}$

Kedua, Secara Metodologi Falsifikasi harus meragukan suatu pengetahuan yang mungkin ada kesalahan dalam mengamati misalnya, bukan angsa yang diamati, melainkan seekor burung. Maka untuk refutasi (penyangkalan) secara sistematis, maka teori harus dirumuskan secara jelas sehingga membuka kemungkinan untuk penyangkalan yang mungkin diajukan. Sebaliknya suatu teori tidak ditinggal dengan gampang, sebab ini mengidentikkan sikap yang tidak kritis terhadap tes, dan dengan begitu berarti teori sendiri tidak diuji sekeras seperti seharusnya. Ketiga, suatu hepotesis atau sistem hipotesis mau diakui memiliki status sebagai hukum atau teori ilmiah. A pabila ia akan menjadi bagian dari ilmu, maka suatu hepotesa harus falsifabel, sebelum melangkah lebih jauh. Contoh soal: semua zat memuai bila dipanasi. Pernyataan itu falsifiabel, ia akan menjadi keliru bila ada keterangan observasi menunjukkan fakta ada suatu zat $x$ tidak memuai ketika dipanasi. ${ }^{26}$

J adi suatu hipotesa adalah falsifiabel apabila terdapat suatu keterangan observasi atau suatu perangkat keterangan observasi yang tidak konsisten dengannya, yakni apabila ia dinyatakan sebagai benar, maka ia akan mengfalsifikasi isi hipotesa itu. Keempat, Teori harus dinyatakan dengan jelas dan cermat dan jelas. Apabila suatu teori diajukan sedemikian samar sehingga tidak jelas apa yang sebenarnya yang diinginkan, maka bilamana diuji dengan observasi atau eksperimen lain, ia dapat diinterpretasikan demikian rupa sehingga selalu konsisten dengan hasil pengujian.

Dengan cara demikian, ia dapat dibela dalam menghadapi falsifikasi. Situasi yang serupa terdapat hubungan dengan ketelitian, makin teliti suatu teori dirumuskan, semakin ia menjadi falsifiabel. Apabila kita menerima bahwa makin falsifiabel suatu teori, makin baik. Contoh misalnya planet-planet bergerak dalam bentuk ellip mengitari matahari adalah lebih teliti dari pada rumusan "planet-planet bergerak dalam bentuk lingkaran tali bulat mengitari matahari". Kelima, Dugaan-dugaan spekulasi yang berani. Rahasia-rahasia ilmu akan berkembang maju dengan bantuan kreatifitas dan mendasar. Semakin besar jumlah teori pendugaan dikonfrontasikan dengan realitas, semakin besar jumlah kesempatan kemajuan yang penting dalam ilmu ${ }^{27}$.

Popper memandang ilmu sebagai suatu perangkai hipotesa yang dikemukakan secara coba-coba dengan tujuan melukiskan secara akurat. Suatu tuntutan bahwa teori harus tinggi

\footnotetext{
${ }^{25}$ Alfon, Epistemologi, 49.

${ }^{26}$ Chalmer, A pa itu , 41.

${ }^{27}$ Ibid., 46.
} 
falsifiabilitasnya, teori harus dinyatakan dengan jelas dan cermat. A pabila suatu teori diajukan sedemikian samar hingga tidak jelas apa sebenarnya yang ingin dinyatakan, maka bila mana diuji dengan observasi atau eksperimen lain, ia dapat diinterpretasikan demikian rupa hingga konsisten dengan hasil pengujian.

Selain prasyarat kriteria Falsifikasi Popper juga menggagas suatu metode praktis untuk memecahkan masalah antara lain: Pertama, teori Varian Trial and Error. Yaitu suatu metode perco baan dan pembuangan kesalahan. Metode ini kata Popper dipakai dalam perkembangan pikiran manusia dan terutama perkembangan filsafat, bisa digambarkan sebagai varian istimewa. Cara kerjanya teori diajukan secara tentatif dan dicobakan. Bila hasil suatu tes menunjukkan bahwa teori itu salah maka teori itu dibuang. Metode percobaan dan pembuangan kesalahan pada hakekatnya adalah metoda penyingkiran. Keberhasilan terutama tergantung pada tiga syarat: yaitu bahwa banyak teori yang diajukan bervariasi serta dilakukan tes yang serius.

Adapun skema metode problem solving sebagi berikut : P1-TS-EE-P2 . U rainnya sebagai berikut: P1 ialah problem awal, TS ialah solusi tentatif, teori yang dicoba diajukan. EE adalah Error elimination atau evaluasi dengan tujuan menemukan dan membuang kesalahan dan P2 ialah merupakan situasi baru yang diakibatkan oleh adanya evaluasi kritis atas solusi alternatif dan tentatif terhadap problema awal, sehingga timbul problem baru. ${ }^{28}$

Skema tersebut di atas menggambarkan suatu proses yang dasarnya bersifat umpan balik. J adi bersifat tidak siklis sebab P2 selalu lain dari pada P1. Bila gagal memecahkan masalah, teori yang dicoba itu nengajukan sesuatu yang baru kepada kita tentang dimana letak kesulitan dan bagaimana syarat-syarat yang harus dipenuhi dan karenanya merupakan situasi problem.

Proses yang digambarkan itu juga bersifat dialektis, dalam arti Hegelian atau Marxian. Sebab metode problem solving memandang kontradiksi sebagai sesuatu yang tak boleh diterima. Menerima kontradiksi menurut Popper, menyebabkan kritik berhenti berfungsi dan dengan begitu membawa kejatuhan ilmu.

Formula motode problem solving seperti diuraikan di atas mengandung beberapa unsur gagasan Popper yang terpenting dan oleh Popper meto de ini sering digunakan untuk memberikan keterangan di banyak bidang. Bahkan boleh dikatakan teori tentang problem solving menjelujuri seluruh karya Popper, baik karya dalam meto dologis maupun karya dalam metafisis. Baik ketika aktif berjibaku dengan kelompok lingkaran Wina maupun ketika berinteraksi dengan para ilmuan di Amerika, J epang, serta Australia.

$\mathrm{Hal}$ ini sangat sesuai dengan sikap kritis yang dikembangkan oleh Popper pada setiap ia berinteraksi dengan karya-karya ilmu pengetahuan sebagai pertanggung jawaban sebagi ilmuan kritis yang selalu ingin menguji dan diuji.

\section{Refleksi atas Pemikiran Karl R. Popper.}

Bila memperhatikan cara kerja yang begitu teliti dan cermatnya Popper, serta sikap keterbukaannya (open anded) ${ }^{29}$ terhadap dunia keilmuan, maka hal yang patut kita tarik benang

${ }^{28}$ Alfon, E pistemologi, 84.

${ }^{29}$ Amin Abdullah, Filsafat K alam di Era Post M odernis (Yogjakarta: Pustaka Pelajar, 1995), 25. 
merahnya ialah bahwa ilmu pengetahuan tidak bersifat mutlak (close) tidak kebal kritik (Truth Claim) tetapi bersifat relatif dan partikularis dengan asumsi akan ada pemikiran baru yang akan merevisi atau megklasifikasi setiap hasil pernyataan serta simpulan pemikiran ilmu pengetahuan.

Salah satu karakter ilmu pengetahuan adalah menerima pengetahuan lain sebagai alat penguji atas kelemahan prosedur, metode atau hasil temuan manusia. Istilah Arkoun "on going 'proces serta on going formation), termasuk juga produk pemikiran Islam (teks klasik) tidak bebas kritik, tidak berlaku sepanjang zaman dan terbuka untuk dikaji (condition sine qua non) bila memungkinkan dilakukan dekontruksi terhadap pemikiran-pemikiran yang dianggap mapan.

Bahwa ilmu pengetahuan merupakan produk manusia dari hasil trial and error (percobaan dan salah) yang mengikuti perkembangan peradaban manusia, maka tidak ada istilah statis, jumud, stagnan atau pintu ijtihad telah tertutup. Pintu ijtihad pemikiran terbuka lebar, senyampang para ilmuan bersemangat untuk melaksanakan riset, maka akan terlahir dinamika baru yang bersifat konstruktif.

Tidak ada otoritas dalam ilmu pengetahuan, sebagai konsekuensinya ilmu pengetahuan terbebas dari kepentingan, terbebas dari nilai, ramalan, pretensi dari manapun yang dapat merusak independensi imajinasi dan ekspresi para ilmuan atau lembaga keilmuan. A palagi upaya untuk mencampuradukkan antara Preudo Sience ke dalam Science.

\section{Daftar Rujukan}

Abdullah, Amin. Filsafat Kalam di era Post Modernis. (Yogjakarta: Pustaka Pelajar, 1995).

Berkson. Psikologi Belajar Karl Popper. (Yogjakarta: Q alam, 2003).

Bertens. Filsafat Barat Kontemporer. (J akarta: PT SUN, 2002).

Chalmer. A pa itu yang dinamakan IImu. (J akarta: H astra Mitra 1963).

Triadi, Alfon. Epitemologi Pemecahan M asalah MenurutKarl Popper. (J akarta, G ramedia, 1991).

Kral Popper. Masyarakat Terbuka dan Musuh-musuhnya. (Yogjakarta, PustakaPelajar, 2003).

- - - - The Logic of Scintific Discovery. (London: Routledge, 1992). Conjecturer and Refulation. (London: Routledge, 1963). 